\title{
INTRODUCTION TO SPECIAL ISSUE: AN EXPLORATION OF CHILD AND YOUTH CARE PEDAGOGY AND CURRICULUM
}

\author{
Johanne Jean-Pierre, Sandrina de Finney, and Natasha Blanchet-Cohen
}

\begin{abstract}
This special issue aims to explore Canadian pedagogical and curricular practices in child and youth care and youth work preservice education with an emphasis on empirical and applied studies that centre students' perspectives of learning. The issue includes a theoretical reflection and empirical studies with students, educators, and practitioners from a range of postsecondary programs in Quebec, Ontario, Alberta, and British Columbia. The empirical articles use various methodologies to explore pedagogical and curricular approaches, including Indigenous land- and water-based pedagogies, ethical settler frontline and teaching practices, the pedagogy of the lightning talk, novel-based pedagogy, situated learning, suicide prevention education, and simulation-based teaching. These advance our understanding of accountability and commitment to Indigenous, decolonial, critical, experiential, and participatory praxis in child and youth care postsecondary education. In expanding the state of knowledge about teaching and learning in child and youth care, we also aspire to validate interdisciplinary ways of learning and knowing, and to spark interest in future research that recognizes the need for education to be ethical, critically engaged, creatively experiential, and deeply culturally and environmentally relevant.
\end{abstract}

Keywords: child and youth care (CYC), youth work, human/social services, pedagogy, curriculum, higher education, praxis, preservice education

Johanne Jean-Pierre PhD, Assistant Professor, School of Child and Youth Care, Ryerson University

Sandrina de Finney PhD, Associate Professor, School of Child and Youth Care, University of Victoria

Natasha Blanchet-Cohen PhD, Associate Professor, Applied Human Sciences, Concordia University

Acknowledgements: First, we are grateful to the authors for engaging in research in the field of child and youth care and youth work and advancing the scholarship of learning and teaching. In addition, we want to thank all the anonymous reviewers who have made this special issue possible with their constructive feedback. Finally, we acknowledge and honour the invaluable input of the participants who volunteered to participate in the studies featured in this special issue, because research would not be possible without them. 


\section{Aims and Scope}

Several college and university programs in child and youth care and youth work aim to prepare future practitioners to work with children, youth, and families using a strengths-based approach, a critical reflexive ethical foundation, and relational practice. While authors have provided insights about how Canadian child and youth care preservice programs can achieve these goals (Bellefeuille et al., 2014; Bellefeuille \& McGrath, 2013; Bellefeuille et al., 2008; CookeDallin et al., 2000; Mann-Feder \& Litner, 2004; Mann-Feder et al., 2017; Phelan, 2005; Ranahan et al., 2015; Sanrud \& Ranahan, 2012; Stuart \& Hare, 2004; VanderVen, 1993; White et al., 2017), only a limited number of empirical studies have been conducted to assess current learning and teaching practices in child and youth care, and even fewer have examined the experiences of students in these programs (Bellefeuille et al., 2018; Bellefeuille et al., 2017; Lashewicz et al., 2014; Ricks, 1997).

This special issue aims to address this gap with scholarly articles that examine the viewpoints of students, educators, practitioners, and collaborators on various curricular and pedagogical processes and learning experiences. The featured articles contribute to expanding the literature on transformative and innovative pedagogical and curricular content for enhancing child and youth care and youth work education, and could inform the Standards for Practice of North American Child and Youth Care Professionals (Association for Child and Youth Care Practice, 2017). Most importantly, the studies bring to light the relevance and applicability of interdisciplinarity in child and youth care and youth work postsecondary education across undergraduate and graduate programs in Canada.

\section{Article Highlights}

The articles stem from research conducted in Quebec, Ontario, Alberta, and British Columbia, and feature a range of applied, Indigenous, innovative, and interdisciplinary pedagogical and curricular activities. In the paragraphs that follow, we outline each article.

Using an Indigenous framework and a storytelling approach, Mowatt et al. present the first part of a two-paper series on Indigenous land- and water-based pedagogies. In response to growing demand for Indigenous research and pedagogies and the underrepresentation of Indigenous graduate students in postsecondary settings, a year-long Indigenous land-based institute coordinated by faculty and led by local WSÁNEĆ and T'Sou-ke nations knowledge-keepers was organized at the University of Victoria; gatherings took place in 2019 and 2020. The article centres upon the individual and collective reflections of participants and highlights the strengths and limitations of Indigenous land- and water-based pedagogies. The stories shared emphasize the significance of Indigenous ways of being and learning, relationality, spirituality, ethics, and community commitment to address colonialism in higher education and support the decolonization of learning with Indigenous postsecondary students. 
De Finney et al. present the second part of the two-paper series on Indigenous land- and water-based pedagogies. Drawing on Indigenous place-based frameworks and a storytelling approach, this article discusses the possibilities and challenges of resurgent Indigenous frontline practice in colonial institutions and contexts. Participants in the Indigenous land-based institute share how resurgent, decolonial praxis can be exercised with Indigenous children, youth, and families. Ethical engagement with family, community ontologies, and relational kinship networks were identified by students and the whole collective circle as central to frontline practices that uphold Indigenous resurgence.

Kouri provides a rich, theoretically informed examination of how various decolonial settler practices can expand and enrich child and youth care ethical and teaching practices. He argues that, in a settler colonial context, settler educators have an ethical responsibility to challenge colonialism and critically examine how settler practices of acknowledgement, self-location, appropriation, consciousness raising, and allyship contribute to decolonization. This article can help settler child and youth care instructors reflect on and transform their current practices. It can also strengthen the current state of knowledge in child and youth care regarding critical, antioppressive, and decolonizing teaching and learning practices.

Using a critical transtheoretical approach, Mackenzie's article focuses on the implications and ethical responsibility of white settler child and youth care practitioners. Drawing on semistructured dialogues with 11 child and youth care practitioners conducted in 2018, Mackenzie unpacks the difficulties of unsettling colonialism, Whiteness, Eurocentrism, fragility, and racism in child and youth care everyday frontline work, and proposes ethical pathways to further our understanding of critical, anti-oppressive, and politicized child and youth care practice and teaching. Mackenzie suggests that "unontologizing" and white settler discomfort can further child and youth care practitioners' engagement in the intellectual and emotional work required to promote transformative action.

Using qualitative data from a mixed-methods study, Jean-Pierre et al. explore how the pedagogy of a lightning talk can foster advocacy skills that enable child and youth care politicized praxis or radical youth work. In 2019, 70 undergraduate students who were enrolled in two child and youth care courses at a Canadian metropolitan university filled out an online questionnaire, including open-ended questions, after they completed the lightning talk. The results point to four areas of learning: public speaking skills, self-regulation strategies, state of preparedness, and advocacy skills. The study shows the value of the lightning talk as a pedagogical tool that enhances students' metacognitive skills and advocacy competencies.

James mobilizes a child and youth care and critical social theory framework to explore students' learning in response to novel-based pedagogy. Using qualitative data from an online questionnaire completed by 38 undergraduate students enrolled in a child and youth care course in 2019, James explored the potential transformative nature of novel-based pedagogy by examining the emotional responses and the connections made by students to previously discussed critical 
theories. The findings suggest that novel-based pedagogy can elicit an empathetic connection and contribute to critical awareness.

Hovington et al.'s study examines students' experiences of a capstone course that integrates seminar teaching, project-based learning, and internship activities in human service agencies. Offered through the Graduate Diploma in Youth Work program at Concordia University, the capstone course was grounded in the principles of the Authentic Situated Learning and Teaching (ASLT) framework and the psychoeducation model. The study drew on student surveys, a focus group, and writing to examine the experiences of two cohorts of interns with a total of 24 participants. The findings suggest that the capstone course supported the transfer of learning among students and promoted the planning and delivery of therapeutic activities and interventions in students' human services placements.

Using critical and social literacy theories, Ranahan explores how students respond to a suicide prevention curriculum tailored for child and youth care practitioners. This grounded theory study took place in Eastern Canada with 13 undergraduate and graduate students enrolled in a youth work program during an 18-month study period in 2015 and 2016. Several data sources were used, including individual audio-recorded interviews, participants' written reflections and creative artifacts, and researcher's observations and reflexive memos. The study points to how learning activities on suicide intervention in a mental health literacy curriculum can shape the processes of becoming and being a youth worker.

Ali et al. focus more generally on the value of service-user involvement in educational processes, as a means of enhancing practical learning opportunities. They consider simulationbased learning in the form of role-play of case scenarios to be particularly valuable for student engagement. Using collaborative self-study, based on the authors' various levels of involvement in the Acting Out program, the paper presents three scenes of a script that unpack personal and professional questions of expertise, participation, and anti-oppressive practice. The paper shows the effectiveness of learning through simulation, as it offers hands-on and real-time feedback in ways that challenges conventional processes of knowledge production.

\section{Overall Contributions}

The articles featured in this special issue contribute to a much-needed body of research and scholarship about teaching and learning in child and youth care and youth work. They showcase the breadth and diversity of modalities and pedagogical practices in college and university settings, as well as across diploma, undergraduate, and graduate programs in Canada.

A significant learning stemming from the studies is the importance of robust documentation, of evaluation and mobilization of interdisciplinary teaching and learning practices, and of student-engaged and student-focused research in our field. Accessible knowledge translation is necessary in order to foster the continued growth and deepening of child and youth care education in the future (White et al., 2017) so that it can remain relevant and responsive to 
students' learning needs. The papers provide a compelling call to action, situating us to respond to new contemporary realities and challenges facing children, youth, families, and communities across the country. Historically, theories from developmental psychology like the ecological theory model (Derksen, 2010), frontline practice and therapeutic concepts (Garfat et al., 2018), and an emphasis on child and youth care-specific content (Phelan, 2005) have influenced the development of many Canadian child and youth care programs. The articles illustrate that expanding our conceptual lenses with insights from diverse child and youth care and youth work practitioners, educators, and collaborators can significantly and critically deepen and broaden learning and teaching in child and youth care programs. This in turn helps us prepare flexible and ethical practitioners to work in an increasingly globalized, complex, diverse, and interconnected world.

Another notable contribution of the collection is the promotion of a dynamic, interdisciplinary understanding of child and youth care, drawing from fields such as psychoeducation, Indigenous studies and Indigenous education, gender and sexuality studies, critical theory, critical whiteness studies, sociology, critical pedagogy, arts-based pedagogies, and many more. Thus, child and youth care education is de facto strengthened by interdisciplinarity to foster more reflexive, equitable praxis to address both everyday and macro-structural challenges impacting the diverse children, youth, families, and communities with whom we work. If we hope to address colonialism and racism, we must clearly frame those as learning objectives and select curricular and pedagogical practices that promote these pressing ethical objectives.

Further, the coauthoring of articles demonstrates the importance of collaborative research and engagement among faculty, sessional instructors, students, and partner agencies and community stakeholders such as Elders, social service organizations, and young people. Indeed, these articles suggest that enhancing practice will come from intersectoral partnerships and flexible methodologies, and by validating alternative ways of knowledge production. A key point of connection among the studies is their commitment to presenting child and youth care pedagogy, theory, research, and practice as inherently and productively interconnected, rather than as distinct and exclusive domains.

Finally, while they outline valuable practices, many of the articles also identify salient challenges, indicating the limitations of developing innovative pedagogies and theoretical frameworks in individual, time-limited courses. These challenges reveal the importance of weaving promising pedagogies across entire programs to ensure more robust implementation; sustained engagement of a rapidly changing student body; and enhanced opportunities for integration of learning outcomes across time and across courses, as well as extending learning into practice settings. Thus, it is important to examine our current college and university programs, establish explicit learning goals, and intentionally plan curricular and pedagogical strategies across several courses to provide a well-rounded educational path. 


\section{A Call to Continue Moving Forward}

This special issue is a step in the right direction to advance our teaching practices. The first four articles encourage us to transform our ethics of care with critical settler-colonial reflexivity, and outline the possibilities of Indigenous resurgence. This opens the door to ask critical questions related to power relations, politicized praxis, and equity. How do we develop curricula and pedagogy that prepare students to understand, name, and challenge frontline practices and policies that seem neutral and conventional but that actually perpetuate racism, colonialism, and other forms of exclusion?

We still need to develop additional tools to prepare students to work with historically marginalized communities and to exercise politicized child and youth care praxis and radical youth work (Bamber \& Murphy, 1999; de Finney et al., 2011; Kouri, 2015; Saraceno, 2012; SkottMyhre, 2006; Yoon, 2012). As it is documented that Indigenous and African Canadian youth are overrepresented in the child welfare and justice systems (Ontario Human Rights Commission, 2018; Pon et al., 2011; Truth and Reconciliation Commission of Canada, 2015), our pedagogies should be established in partnerships led by members of these communities. For instance, the Truth and Reconciliation Commission (2015) has called on postsecondary institutions to take leadership in redressing their role in maintaining damaging colonial practices and policies. An ethical imperative in this process is ensuring that Indigenous and decolonial pedagogical processes and principles are integrated throughout child and youth care programs; that they are initiated and delivered in ethical and meaningful ways with and by Indigenous instructors, practitioners, and communities; that instructors avoid homogenizing, tokenising, exploiting, and appropriating Indigenous knowledges; and that we examine critically how postsecondary education and frontline practice participate in settler colonialism.

Moreover, the United Nations General Assembly Report (2017) has recommended that Canada address racism, inequities, and the existing gaps between policies and practices in regards to African Canadians to promote recognition, development, and justice. Across our programs, we can reflect upon how we welcome transformative, justice-oriented, and anti-racist ethos led by and with African Canadian instructors, practitioners, and communities to avoid the reproduction of anti-Black racist practices. This vital work can be productively supported by a wealth of practice and research worldviews and frameworks that have been historically excluded from the child and youth care canon, including Indigenous philosophies, knowledges, and pedagogies (Cooke-Dallin et al., 2000; de Finney, 2015; Hansen, 2018; Simpson, 2014), or Africentric, Black feminist, and anti-racist intellectual work and community leadership initiatives (Amponsah \& Stephen, 2020; Daniel \& Jean-Pierre, 2020; Munroe, 2017). There is also space to examine how we address the specific needs of immigrant and refugee children and youth in urban and rural settings. We suggest that future inquiries investigate the pedagogical and curricular tools that support anti-oppressive equity and enable students to develop transformative, context-dependent, strengths-based practices. 


\section{Conclusion}

We are deeply grateful to the authors, students, and collaborators who have invited us to reimagine our current college and university pedagogies and expand our understanding of accountability and commitment. We hope that this special issue will encourage researchers and educators to explore creative and critical pedagogies in child and youth care and youth work programs, to value the perspectives of students and community members in the learning process, and to welcome Indigenous, alternative, and interdisciplinary ways of knowledge production. While the studies speak specifically to the Canadian context, exploring other countries' teaching practices can also enrich our horizons and inspire innovation. In fact, international and comparative inquiries could yield interesting insights into how national and sociolinguistic contexts shape postsecondary students' responses to different curricular and pedagogical practices. This issue also points to the need to further question and examine how we prepare students to engage in frontline work with historically excluded communities and confront intersecting forms of colonialism, racism, and discrimination. In sum, this special issue sparks enthusiasm for pedagogical research in our field and contributes to the vibrant scholarship of learning and teaching in child and youth care and youth work programs. 
International Journal of Child, Youth and Family Studies (2020) 11(3): 1-11

\section{References}

Amponsah, P., \& Stephen, J. (2020). Developing a practice of African-centred solidarity in child and youth care. International Journal of Child, Youth \& Family Studies, 11(2), 6-24. doi:10.18357/ijcyfs112202019516

Association for Child and Youth Care Practice. (2017). Standards for practice of North American child and youth care professionals. https://www.acycp.org/images/pdfs/ethics_and_practices_ACYCP_v2-1.pdf

Bamber, J., \& Murphy, H. (1999). Youth work: The possibilities for critical practice. Journal of Youth Studies, 2(2), 227-242. doi:10.1080/13676261.1999.10593037

Bellefeuille, G., Crazyboy, L., Dela Cruz, J., Gladue, A., \& Walper, H. (2018). A qualitative inquiry in to the impact of an arts-based, self-portrait assignment on third year child and youth care students. Research Journal of Education, 4(3), 36-43.

Bellefeuille, G., Dalton, K. H., Neuman, S., Ammouneh, A., Anthony, C., Bautista, M., Benzon, G., Deol, J., Smith, L., Reid, K.-A., \& Thang, S. (2017). Traversing the threshold in child and youth care education: A qualitative inquiry into the meaning-making experience of student participants in an international study tour. Research Journal of Education, 3(2), 12 22.

Bellefeuille, G., Ekdhal, C., Kent, L., \& Kluczny, M. (2014). A course-based creative inquiry approach to teaching introductory research methods in child and youth care undergraduate education. International Journal of Teaching and Education, 2(2), 1-9.

Bellefeuille, G., \& McGrath, J. (2013). A relational-centred international education partnership: A phenomenological inquiry into the lived experiences of child and youth care/social care students and faculty. Contemporary Issues in Education Research, 6(3), 279-288. doi:10.19030/cier.v6i3.7897

Bellefeuille, G., McGrath, J., \& Jamieson, D. (2008). A pedagogical response to a changing world: Towards a globally-informed pedagogy for child and youth care education and practice. Child and Youth Services Review, 30(7), 717-726. doi:10.1016/j.childyouth.2007.11.013

Cooke-Dallin, B., Rosborough, T., \& Underwood, L. (2000). The role of elders in child and youth care education. Canadian Journal of Native Education, 24(2), 82-91.

Daniel, B.-J., \& Jean-Pierre, J. (2020). Re-imagining child and youth care practice with African Canadian youth. International Journal of Child, Youth \& Family Studies, 11(2), 25-39. doi:10.18357/ijcyfs112202019517 
International Journal of Child, Youth and Family Studies (2020) 11(3): 1-11

de Finney, S., Dean, M., Loiselle, E., \& Saraceno, J. (2011). All children are equal, but some are more equal than others: Minoritization, structural inequities, and social justice praxis in residential care. International Journal of Child, Youth and Family Studies, 2(3-4), 361-384. doi:10.18357/ijcyfs23/420117756

de Finney, S. (2015). Playing Indian and other settler stories: Disrupting Western narratives of Indigenous girlhood. Continuum, 29(2), 169-181. doi:10.1080/10304312.2015.1022940

Derksen, T. (2010). The influence of ecological theory in child and youth care: A review of the literature. International Journal of Child, Youth and Family Studies, 1(3-4), 326-339. doi:10.18357/ijcyfs13/420102091

Garfat, T., Freeman, J., Gharabaghi, K., \& Fulcher, L. (2018). Characteristics of a relational child and youth care approach revisited. CYC-Online, 236, 7-45.

Hansen, J. (2018). Cree Elders' perspectives on land-based education: A case study. Brock Education Journal, 28(1), 74-91. doi:10.26522/brocked.v28i1.783

Kouri, S. (2015). The canonical self and politicized praxis: A tracing of two concepts. International Journal of Child, Youth and Family Studies, 6(4), 595-621. doi:10.18357/ijcyfs.64201514290

Lashewicz, B., McGrath, J., \& Smyth, M. (2014). Mask making in human services education: A case for student engagement. Journal of Teaching in Social Work, 34(2), 182-198. doi: $10.1080 / 08841233.2014 .897298$

Mann-Feder, V. R., \& Litner, B. (2004). A normative re-educative approach to youthwork education: Department of Applied Human Sciences, Concordia University. Child and Youth Care Forum, 33(4), 275-286. doi:10.1023/B:CCAR.0000035377.36618.d9

Mann-Feder, V. R., Scott, D. G., \& Hardy, B. (2017). The future of child and youth care education: Insights from Canada. International Journal of Child, Youth and Family Studies, 8(2), 1-10. doi:10.18357/ijcyfs82201717722

Munroe, T. (2017). Enriching relational practices with critical anti-Black racism advocacy and perspectives in schools. Relational Child \& Youth Care Practice, 30(3), 32-45.

Ontario Human Rights Commission. (2018). Interrupted childhoods: Over-representation of Indigenous and Black children in Ontario child welfare [Report]. http://www.ohrc.on.ca/sites/default/files/Interrupted childhoods_Over-representation of Indigenous and Black children in Ontario child welfare accessible.pdf

Phelan, J. (2005). Child and youth care education: The creation of articulate practitioners. Child and Youth Care Forum, 34(5), 347-355. doi:10.1007/s10566-005-5907-4 
International Journal of Child, Youth and Family Studies (2020) 11(3): 1-11

Pon, G., Gosine, K., \& Phillips, D. (2011). Immediate response: Addressing anti-Native and antiBlack racism in child welfare. International Journal of Child, Youth and Family Studies, 2(3-4), 385-409. doi:10.18357/ijcyfs23/420117763

Ranahan, P., Blanchet-Cohen, N., \& Mann-Feder, V. (2015). Moving towards an integrated approach to youth work education. International Journal of Child, Youth and Family Studies, 6(4), 516-538. doi:10.18357/ijcyfs.64201514286

Ricks, F. (1997). Perspectives on ethics in child and youth care. Child and Youth Care Forum, 26(3), 187-204. doi:10.1007/BF02589385

Sanrud, H., \& Ranahan, P. (2012). Pedagogical encounters of the case-based kind. International Journal of Child, Youth and Family Studies, 3(2-3), 234-247. doi:10.18357/ijcyfs32$\underline{3201210868}$

Saraceno, J. (2012). Mapping whiteness and coloniality in the human service field: Possibilities for a praxis of social justice in child and youth care. International Journal of Child, Youth and Family Studies, 3(2-3), 248-271. doi:10.18357/ijcyfs32-3201210869

Simpson, L. (2014). Land as pedagogy: Nishnaabeg intelligence and rebellious transformation. Decolonization: Indigeneity, Education \& Society, 3(3), 1-25.

Skott-Myhre, H. (2006). Radical youth work: Becoming visible. Child and Youth Care Forum, 35(3), 219-229. doi:10.1007/s10566-006-9010-2

Stuart, C. A., \& Hare, F. G. (2004). Entry to practice and beyond: Aspiring to an accessible educational continuum at Ryerson. Child and Youth Care Forum, 33(4), 287-310. doi:10.1023/B:CCAR.0000035378.52277.d3

Truth and Reconciliation Commission of Canada. (2015). Honouring the truth, reconciling for the future: Summary of the final report of the Truth and Reconciliation Commission of Canada. Government of Canada. http://nctr.ca/reports.php

United Nations General Assembly. (2017). Report of the working group of experts on people of African descent on its mission to Canada. Human Rights Council. https://ansa.novascotia.ca/sites/default/files/files/report-of-the-working-group-of-expertson-people-of-african-descent-on-its-mission-to-canada.pdf

VanderVen, K. (1993). Advancing child and youth care: A model for integrating theory and practice through connecting education, training, and the service system. Child and Youth Care Forum, 22(4), 263-284. doi:10.1007/BF00756952

Yoon, J.-S. (2012). Courageous conversations in child and youth care: Nothing lost in the telling. International Journal of Child, Youth and Family Studies, 3(2-3), 164-186.

doi:10.18357/ijcyfs32-3201210864 
International Journal of Child, Youth and Family Studies (2020) 11(3): 1-11

White, J., Kouri, S., \& Pacini-Ketchabaw, V. (2017). Risking attachments in teaching child and youth care in twenty-first-century settler colonial, environmental and biotechnological worlds. International Journal of Social Pedagogy, 6(1), 43-63.

doi:10.14324/111.444.ijsp.2017.v6.1.004 


\section{Biographies}

Dr. Johanne Jean-Pierre is an Assistant Professor in the School of Child and Youth Care at Ryerson University. She conducts bilingual research projects in the fields of sociology of education and child and youth studies. Her current research program explores postsecondary trajectories and experiences, alternative school discipline practices, and child and youth care pedagogy. Her research focuses on the social-cultural dynamics that can inform promising policies and practices to work with refugee and immigrant youth, African Canadian communities, and linguistic minorities such as Francophone minority communities.

Dr. Sandrina de Finney is a faculty member in the School of Child and Youth Care, University of Victoria, and lead researcher for Sisters Rising: Honouring Indigenous Body and Land Sovereignty (sistersrising.uvic.ca), part of an international study that promotes Indigenous-led, youth-engaged, land- and water-based gender well-being and resurgence.

Dr. Natasha Blanchet-Cohen is an Associate Professor in the Department of Applied Human Sciences at Concordia University and Graduate Director of the Youth Work diploma. She is the co-chair of the Quebec youth research network. Dr. Blanchet-Cohen's work focuses on child rights and participation, resiliency, social inclusion, and systems change and innovation. As an interdisciplinary scholar, she has led national research initiatives on building resilient communities through youth engagement, and holds a particular interest in immigrant and Indigenous youth. Her work explores the opportunities and limitations for immigrant and Indigenous young people's being change agents in their schools, homes, and communities, as well as the perspectives of youth in providing for rights-based and culturally-safe services and programs. 